\title{
Cyclooxygenase and prostaglandins in somatic cell populations of the testis
}

\author{
Mónica B Frungieri ${ }^{1,2}$, Ricardo S Calandra ${ }^{1}$, Artur Mayerhofer ${ }^{3}$ and María E Matzkin ${ }^{1,2}$ \\ ${ }^{1}$ Instituto de Biología y Medicina Experimental, Consejo Nacional de Investigaciones Científicas y Técnicas \\ (CONICET), Vuelta de Obligado 2490, Buenos Aires 1428, Argentina, ${ }^{2}$ Departamento de Bioquímica Humana, \\ Facultad de Medicina, Universidad de Buenos Aires, Paraguay 2155, Buenos Aires 1121, Argentina and \\ ${ }^{3}$ Anatomie III - Zellbiologie, Universität München (LMU), Schiller Strasse 42, D-80336 Munich, Germany
}

Correspondence should be addressed to M B Frungieri; Email: mfrungieri@fmed.uba.ar

\begin{abstract}
Prostaglandins (PGs) are synthesized through the action of the rate-limiting enzyme cyclooxygenase (COX) and further specific enzymes. The development of Cox-deficient mice in the 1990s gave insights into the reproductive roles of PGs. Female Cox-knockout mice were subfertile or infertile. Interestingly, fertility was not affected in male mice deficient in Cox, suggesting that PGs may not be critical for the functioning of the testis. However, this conclusion has recently been challenged by observations of important roles for PGs in both physiological and pathological processes in the testis. The two key somatic cell types in the testis, Leydig and Sertoli cells, express the inducible isoenzyme COX2 and produce PGs. Testicular COX2 expression in these somatic cells is regulated by hormonal input (FSH, prolactin (PRL), and testosterone) as well as by IL1 $\beta$. PGs modulate steroidogenesis in Leydig cells and glucose uptake in Sertoli cells. Hence, the COX2/PG system in Leydig and Sertoli cells acts as a local modulator of testicular activity, and consequently may regulate spermatogenic efficiency. In addition to its expression in Leydig and Sertoli cells, COX2 has been detected in the seminiferous tubule wall, and in testicular macrophages and mast cells of infertile patients. These observations highlight the possible relevance of PGs in testicular inflammation associated with idiopathic infertility. Collectively, these data indicate that the COX2/PG system plays crucial roles not only in testicular physiology (i.e., development, steroidogenesis, and spermatogenesis), but more importantly in the pathogenesis or maintenance of infertility status in the male gonad. Further studies of these actions could lead to new therapeutic approaches to idiopathic male infertility.

Free German abstract: A German translation of this abstract is freely available at http://www.reproduction-online.org/content/149/4/ R169/suppl/DC1.
\end{abstract}

Free Spanish abstract: A Spanish translation of this abstract is freely available at http://www.reproduction-online.org/content/149/4/ R169/suppl/DC2.

Reproduction (2015) 149 R169-R180

\section{Introduction}

Prostaglandins (PGs) are bioactive lipid substances derived from arachidonic acid. Arachidonic acid is generated from phospholipid hydrolysis catalyzed by combined phospholipase $\mathrm{A}_{2}\left(\mathrm{PLA}_{2}\right)$ and cyclooxygenase (COX) or lipoxygenase activities. Arachidonic acid can also be generated from diacylglycerol (DAG) by the action of a DAG lipase (Harnett \& Goodrigde 2005).

PGs, which are found in most tissues and organs, are produced by almost all nucleated cells. They were discovered in the 1930s and named prostaglandins because they were originally thought to be prostatic products (Goldblatt 1933, Von Euler 1935).

PGs are involved in a diversity of physiological and pathological systems such as regulation of inflammatory and immune responses, cell growth, intraocular pressure, calcium movement, contraction and relaxation of vascular smooth muscle cells, aggregation and disaggregation of platelets, glomerular filtration rate in the kidney, sensitivity of spinal neurons to pain, body temperature in response to fever, and parturition (Narumiya 2007).

The biosynthetic pathway of PGs is initiated when COX catalyzes two sequential reactions, cyclooxygenation of arachidonic acid to PGG and a subsequent peroxidation in which $\mathrm{PGG}$ is reduced to $\mathrm{PGH}$. The resulting $\mathrm{PGH}$ is converted to other bioactive $\mathrm{PG}$ isomers by the action of synthases and ketoreductases, reactions of dehydration, and non-enzymatic isomerization (Fig. 1; Simmons et al. 2004, Frungieri et al. 2006). The majority of the biologically active PGs belong to series 2, characterized by the presence of two double bonds in 


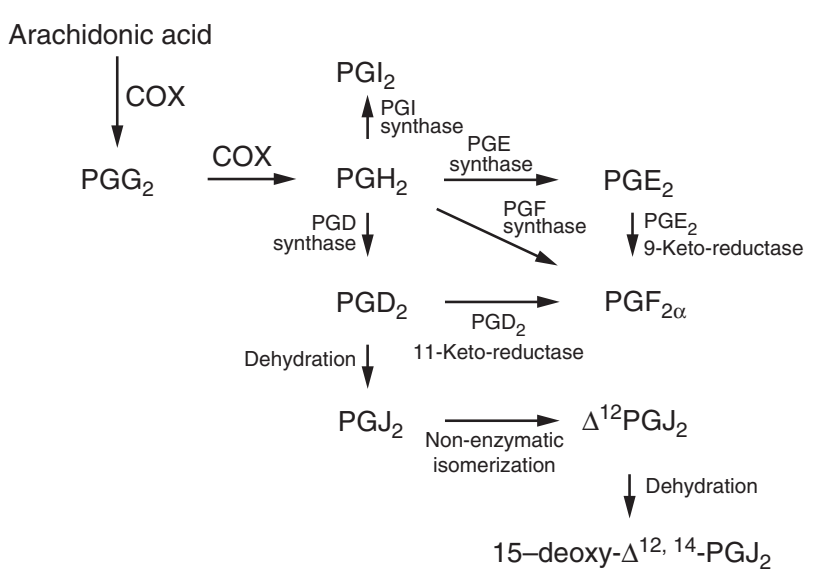

Figure 1 Schematic representation of the prostaglandin (PG) biosynthetic pathway. The process is initiated by the action of the cyclooxygenase (COX) enzyme, which catalyzes both the conversion of arachidonic acid into $\mathrm{PGG}_{2}$, and the subsequent reduction of $\mathrm{PGG}_{2}$ to $\mathrm{PGH}_{2}$. Afterward, $\mathrm{PGH}_{2}$ is the common precursor for the synthesis of the remaining major PGs.

the hydrocarbon structure (Simmons et al. 2004, Frungieri et al. 2006).

COX, the rate-limiting enzyme of PG biosynthesis, is also known as prostaglandin $\mathrm{H}$ synthase (PGHS) or prostaglandin endoperoxide synthase (PTGS). COX is present in two distinct isoforms, types 1 and 2, encoded by separate genes (Smith \& Langenbach 2001, Simmons et al. 2004). COX1, commonly known as the constitutive isoform, is found in most cell types, while COX2, the inducible form, appears to be expressed only during early stages of cell differentiation or replication, in response to varying stimuli such as cytokines and mitogenic factors. COX2 expression has been described in physiological and pathological processes including inflammation, angiogenesis, bone absorption, gastric ulceration, kidney diseases, brain disorders, and female genital tract disorders (Katori \& Majima 2000). Furthermore, COX2 is overexpressed in many types of cancer, including breast, colon, lung, and prostate cancers (Harris 2009).

Depending on the biological process, COX isoenzymes can act individually, in concert, or in cases where one isoenzyme is lacking, in a compensatory manner (Smith \& Langenbach 2001). Recently, new variants of COX have been discovered, such as COX3 and $P C O X 1$, splice variants that affect the coding region of COX1, as well as a number of alternatively polyadenylated transcripts of $C O X$ and single nucleotide polymorphisms (SNPs; Simmons et al. 2004). COX variants and mutants are likely to yield altered or expanded biological function.

$D P, E P, F P, I P$, and TP are serpentine plasma membrane-localized prostanoid receptors that bind PGD, PGE, PGF, PGI, and thromboxane respectively. In addition, several prostanoids, of which 15 -deoxy- $\Delta^{12,14}$ $\mathrm{PGJ}_{2}\left(15 \mathrm{~d}-\mathrm{PG} \mathrm{J}_{2}\right)$ is the most potent, may activate the peroxisome proliferator-activated receptor gamma (PPAR $\gamma$ ) members of the steroid/thyroid family of nuclear hormone receptors, which act as transcription factors and may thus directly influence gene transcription (Simmons et al. 2004, Narumiya 2007).

\section{COX and PGs in the human testis}

In the 1990s, the development of Cox1- and Cox2deficient mice yielded insights into the reproductive roles of PGs. While female Cox 2 knockout mice are infertile, those deficient in Cox 1 have difficulties with parturition but produce litters with normal weight. In contrast, fertility is not affected in male mice deficient in Cox1 or Cox2 (Langenbach et al. 1999). These early reports suggested that PGs may not be critical to testicular function. However, this view has recently been challenged by novel observations. It has been reported that paracetamol and some nonsteroidal antiinflammatory drugs (NSAIDs) such as aspirin and indomethacin induce endocrine disturbances in the human fetal testis capable of interfering with testicular descent (Mazaud-Guittot et al. 2013). Furthermore, $\mathrm{PGD}_{2}$ influences male germ cell differentiation in the fetal mouse testis (Moniot et al. 2014), and it has been proposed that the hematopoietic $\mathrm{PGD}_{2}$ synthase participates in the SOX9 nuclear translocation necessary for the process of Sertoli cell differentiation (Rossitto et al. 2015).

PG receptors have been described in Leydig cells (i.e., EP1, DP, FP, TP, and PPAR $\gamma$ receptors; Walch et al. 2003, Frungieri et al. 2006, Schell et al. 2007, Kowalewski et al. 2009, Pandey et al. 2009), Sertoli cells (e.g., EP1, EP2, EP3, EP4, DP, IP, FP, and PPAR $\gamma$ receptors; Ishikawa \& Morris 2006, Winnal et al. 2007, Kristensen et al. 2011, Matzkin et al. 2012a), and the seminiferous tubule wall (PPAR $\gamma$ receptors; Frungieri et al. 2002a). DP prostanoid receptors have also been detected in germ cells of the fetal mouse testis (Moniot et al. 2014), whereas functional PPAR $\gamma$ and PGE receptors have been found in sperm (Schaefer et al. 1998, Santoro et al. 2013).

PGs, mainly those from the PGE and 19-hydroxy-PGE series, are present in human seminal plasma. Several reports have claimed that there is a correlation between PG levels in semen and otherwise unexplained male infertility (Kelly 1978). The lipocalin and hematopoietic $\mathrm{PGD}_{2}$ synthases are also detected in seminal plasma and their concentrations are lower in oligozoospermic men than in normozoospermic men (Tokugawa et al. 1998). PGs in human seminal plasma are mostly secreted from the seminal vesicles. Nevertheless, testicular secretions also contribute up to $5 \%$ of the composition of the semen (Thibodeau \& Patton 2012).

Data from our group revealed that COX is not detectable by immunohistochemistry in normal adult human testes without morphological abnormalities. 
However, the inducible isoenzyme COX2 is expressed by several cell types in testicular biopsies of men with impaired spermatogenesis and infertility (Frungieri et al. 2002a, Welter et al. 2011). They include Leydig cells, Sertoli cells, and cells of the tubular wall that present an altered morphology (Figs 2 and 3; Schell et al. 2008, Matzkin et al. 2010). COX2 was also found in testicular immune cells, namely mast cells and macrophages (Matzkin et al. 2010, Welter et al. 2011, Rossi et al. 2014).

Similarly, Hase et al. (2003) did not detect COX expression in the normal human testis, but described induction of COX1 and COX2 in testicular cancer. Additionally, lipocalin and hematopoietic $\mathrm{PGD}_{2}$ synthases are expressed in testes from patients with impaired spermatogenesis (Schell et al. 2007).

These data suggest that, in pathological situations, the human testis is capable of synthesizing PGs. In this regard, we have recently described the presence of the PG metabolite, $15 \mathrm{~d}-\mathrm{PG}_{2}$, in biopsies of patients suffering from idiopathic infertility (Kampfer et al. 2012).

Overall, the wide distribution of PG receptors and synthesizing enzymes in the testis emphasizes the plethora of functions and potential key roles exerted by these bioactive lipid substances on testicular development, steroidogenesis, sperm maturation, and male fertility.

Physiological studies cannot be performed using human testicular biopsies. In the search for an appropriate model, our laboratory turned to the Syrian hamster. It was chosen as the experimental model because the exposure of male adult animals to $<12.5 \mathrm{~h}$ of light/day for $3-4$ months
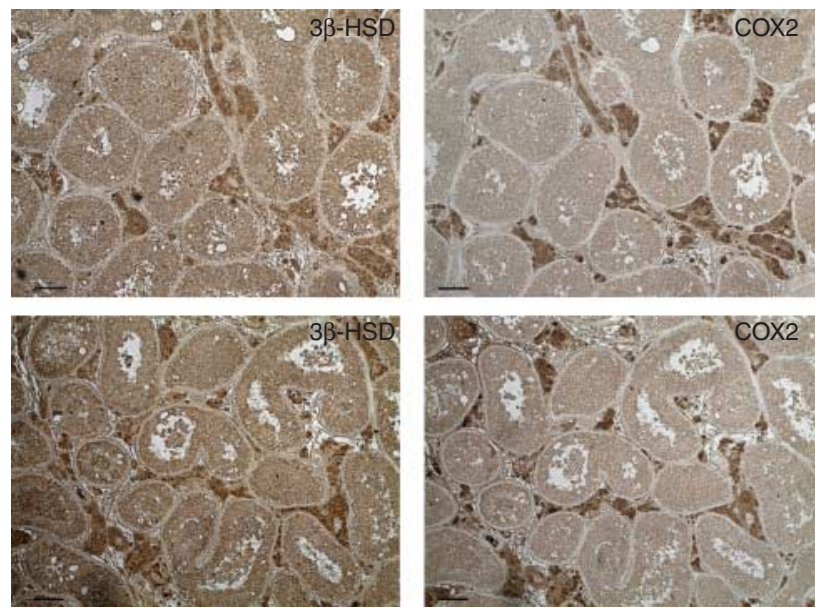

Figure 2 Immunohistochemical images of consecutive testicular sections of a patient with hypospermatogenesis immunostained for $3 \beta$-hydroxysteroid dehydrogenase (3 $\beta$-HSD) and cyclooxygenase 2 (COX2). Most, but not all, $3 \beta-\mathrm{HSD}$-immunoreactive Leydig cells found in the human testis are also positively stained for COX2. A polyclonal rabbit anti-COX2 serum (Oxford Biomedical Research, Oxford, UK, $1: 200$ ) and a polyclonal rabbit anti-3 $\beta$-HSD serum (kindly provided by Prof. Dr J I Mason, University of Edinburgh Centre of Reproductive Biology, Scotland, 1:2000) were used. Bar: $100 \mu \mathrm{m}$.
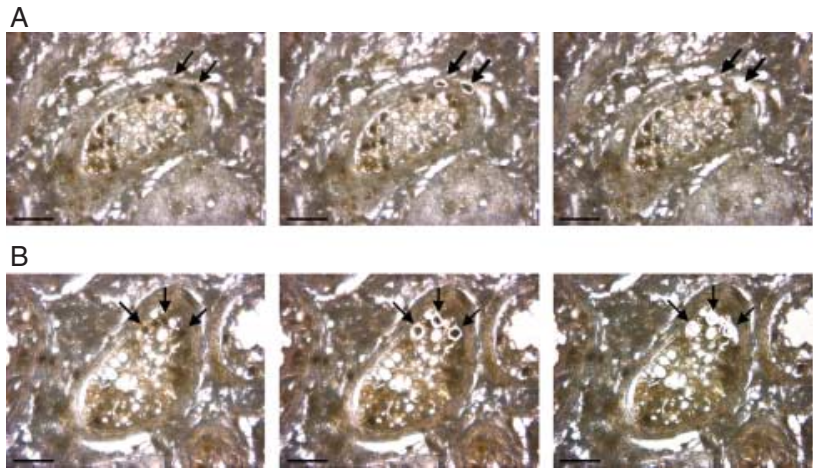

C

AR-immunoreactive

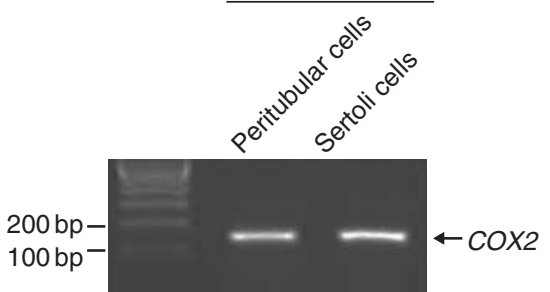

Figure 3 Using laser capture microdissection, androgen receptor (AR)immunoreactive peritubular (A) and Sertoli (B) cells (arrows) were isolated from a testicular biopsy of a patient suffering from germ cell arrest, and then subjected to RT-PCR studies. (A) Each panel depicts the same specimen before laser microdissection (left), after u.v. laser delimitation of AR-immunoreactive peritubular cells (arrows; middle), and after IR laser microdissection (right) of target cells. A polyclonal rabbit anti-AR serum (Santa Cruz Biotechnology, Inc., 1:200) was used. Bar, $50 \mu \mathrm{m}$. (B) Each panel depicts the same specimen before laser microdissection (left), after u.v. laser delimitation of AR-immunoreactive Sertoli cells (arrows; middle), and after IR laser microdissection (right) of target cells. A polyclonal rabbit anti-AR serum (Santa Cruz Biotechnology, Inc., 1:200) was used. Bar, $50 \mu \mathrm{m}$. (C) COX2 mRNA expression was detected in human peritubular and Sertoli cells by RT-PCR assays performed with oligonucleotide primers from Matzkin et al. (2010). PCR products were separated on $2 \%$ agarose gels and visualized with ethidium bromide. The identity of the cDNA products was confirmed by sequencing, using a fluorescence-based dideoxy sequencing reaction and an automated sequence analysis on an $\mathrm{ABI}$ 373A DNA sequencer.

results in a severe testicular regression with morphological features resembling those observed in biopsies of patients suffering from hypospermatogenesis and germ cell arrest. For instance, seminiferous tubules in photoperiodically regressed hamster testes contain mostly Sertoli cells, spermatogonia, and a few primary spermatocytes (Fig. 4; Sinha Hikim et al. 1988, Rossi et al. 2014).

\section{COX and PGs in Leydig cells}

We initiated the investigation of COX expression in Syrian hamster testes, and although COX1-immunoreactive cells were not detected, immunoperoxidase staining revealed the presence of COX2 in the cytoplasm of interstitial cells, showing the characteristic punctate chromatin pattern of Leydig cells in peripubertal, pubertal, and adult hamster testes. Surprisingly, testicular 

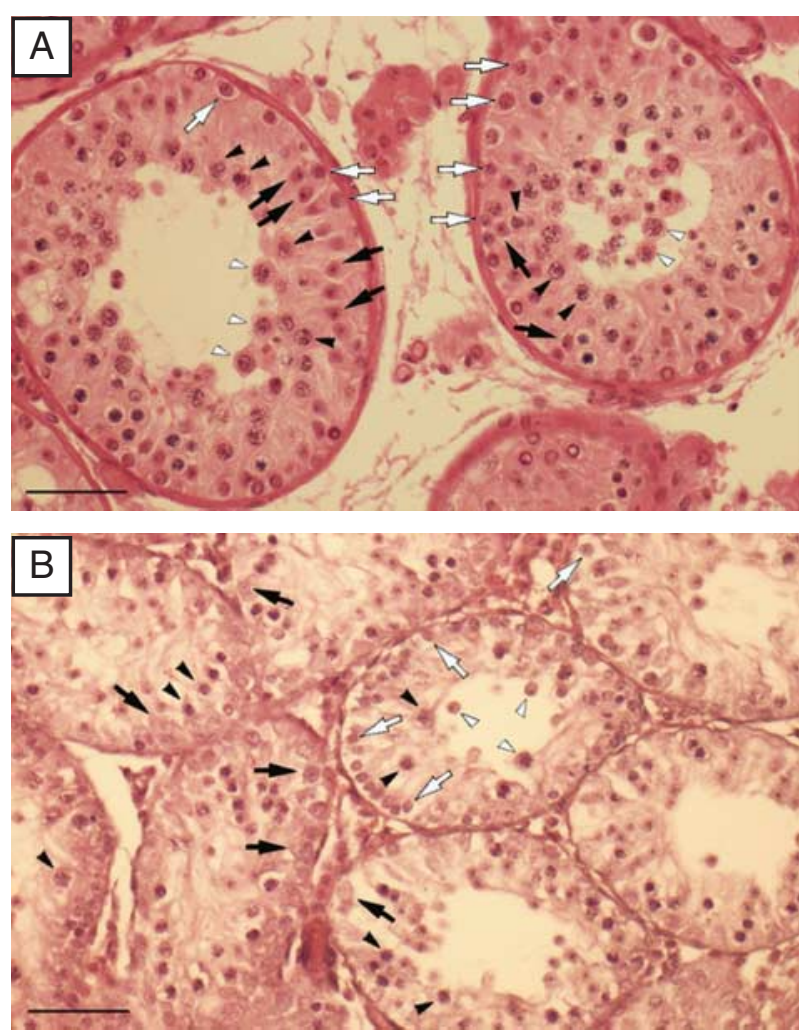

Figure 4 Testicular morphology in Bouin's fluid-fixed and hematoxylinstained cross-sections of a patient suffering from hypospermatogenesis (A) and a reproductively regressed adult hamster (B). Sertoli cells (black arrows), spermatogonia (white arrows), spermatocytes (black arrowheads), and prematurely detached spermatocytes (white arrowheads) are shown. Bar, $50 \mu \mathrm{m}$.

expression of COX2 was barely detectable when adult hamsters were exposed to light-deprivation conditions (Frungieri et al. 2006). Thus, although testes from regressed hamsters are histologically similar to biopsies of infertile patients, they are deficient in COX2 expression, a typical feature of Leydig cells in the pathological human testis. This discrepancy may imply that PGs play distinctly different roles in testes of different species (Frungieri et al. 2006). Thus, COX2 and PGs may have a biological relevance in the pathogenesis or maintenance of infertility states in men. Conversely, considering that COX2 levels are much more abundant in Leydig cells of reproductively active hamsters than in testes of photoperiodically regressed animals, we propose that PGs could act as physiological mediators involved in the modulation of steroidogenic cell function in seasonal breeders.

In contrast to our observations in testes of reproductively active hamsters, we failed to detect COX2 by immunohistochemistry in testes from other species (i.e., rhesus monkeys, pigs, BALBc mice, Wistar rats, and Sprague-Dawley rats; Frungieri et al. 2006). However, Parillo et al. (2011) have recently described COX immunoreactivity in Leydig cells of the alpaca Lama pacos. Furthermore, some authors (Wang et al. 2005, Balaji et al. 2007, Winnal et al. 2007) have reported COX2 expression in mouse and rat Leydig cells using more sensitive assays such as western blot, quantitative PCR, and enzyme activity assays. These data allow us to speculate about the existence of species-specific levels of COX2 expression in Leydig cells, which may be explained by the evolutionary divergence in testicular coding sequences (Oduru et al. 2003) and/or the existence of a marked variation between different species in the regulation of the hypothalamic-pituitarytesticular axis by hormones and local factors (Lincoln 2000).

Revisiting the issue of COX2 expression in hamster Leydig cells, this isoenzyme is detected mainly in reproductively active pubertal and adult hamsters with increased circulating concentrations of luteinizing hormone (LH), prolactin (PRL), and androgens (Frungieri et al. 2006, Matzkin et al. 2009, 2012b). On the other hand, in adult hamsters exposed to a short-day photoperiod and also in prepubertal hamsters, testicular COX2 is barely detected, coinciding with low serum concentrations of LH, PRL, and androgens (Frungieri et al. 2006, Matzkin et al. 2009, 2012b). These results suggest that some hormones (LH, PRL, and/or androgens) could be involved in the regulation of testicular COX2 expression and PG production.

The unique expression of PGD synthase in adult Leydig cells had already been described (O'Shaughnessy et al. 2002, Schell et al. 2007). However, to our knowledge, the potential role of COX2 as a marker of mature active Leydig cells during cell development has not previously been suggested.

In vitro experiments performed in Leydig cells purified from reproductively active adult hamsters incubated in the presence or absence of $\mathrm{LH} /$ human chorionic gonadotropin (hCG) and testosterone, and with or without the addition of bicalutamide (a pure nonsteroidal antiandrogen) to the incubation medium, showed an up-regulation of COX2 expression and $\mathrm{PGF}_{2 \alpha}$ production. This $\mathrm{LH}$ action is not derived from a direct mechanism but rather from its stimulatory role in testosterone synthesis (Matzkin et al. 2009). In fact, testosterone effects in hamster Leydig cells are exerted via androgen receptors (ARs; Matzkin et al. 2009). The classical mechanism of testosterone action involves binding of this steroid to the cytoplasmic AR, translocation of the newly formed complex into the nucleus, its binding to specific DNA regulatory elements, and, finally, gene transcription regulation. In addition to this classical pathway, there is growing evidence indicating that androgens can trigger cellular processes through rapid, non-genomic mechanisms (Foradori et al. 2008). In this context, the stimulatory effect of testosterone on COX2/PGF ${ }_{2 \alpha}$ in hamster Leydig cells takes place via a non-classical mechanism that involves phosphorylation of ERK1/2 (Matzkin et al. 2009). 
On the other hand, PRL also mediates up-regulation of COX2 expression and stimulation of $\mathrm{PGD}_{2}$ and $\mathrm{PGF}_{2 \alpha}$ production in hamster Leydig cells through activation of p38-MAPK and JAK2 (Matzkin et al. 2012b). Posttranslational modifications of the PRL molecule including glycosylation, tyrosine sulfation, phosphorylation, and deamination may well represent a key mechanism for creating diversity in the biological actions of this hormone (Sinha 1992). In particular, pituitaries from reproductively active hamsters contain PRL charge analogs with pl of 5.16, 4.61, and 4.34. The exposure of adult hamsters to a short-day photoperiod of $6 \mathrm{~h}$ light/ day results in a decline in PRL pituitary levels and in the presence of less acidic PRL charge analogs with a $\mathrm{pl}$ of 5.44. Interestingly, the more acidic PRL charge analogs present in the pituitaries of reproductively active hamsters strongly induce COX2 expression in hamster Leydig cells. By contrast, the less acidic analogs detected in the pituitaries of regressed animals have no effect (Matzkin et al. 2012b). The stimulatory effect of more acidic PRL charge analogs on COX2 expression in hamster Leydig cells takes place through a mechanism that involves the pro-inflammatory cytokine IL1 $\beta$ (Matzkin et al. 2012b). It has been shown that IL1 $\beta$ induces COX2 expression and $\mathrm{PGD}_{2}$ and $\mathrm{PGF}_{2 \alpha}$ production in mouse TM3 Leydig cells (Matzkin et al. 2010). The expression of the IL1R1 functional receptor of IL1 $\beta$ in Leydig cells has been described not only in rodents (hamsters and mice) but also in humans (Matzkin et al. 2010, 2012b).

The prostanoid receptors DP and FP have been described in both hamster and human Leydig cells (Frungieri et al. 2006, Schell et al. 2007). While $\mathrm{PGD}_{2}$ has a stimulatory effect on basal testosterone production in hamster Leydig cells (Schell et al. 2007), PGF $_{2 \alpha}$ exerts an inhibitory effect on the expression of the StAR protein and the $17 \beta$-hydroxysteroid dehydrogenase $(17 \beta$-HSD or HSD17B1) enzyme, as well as on the synthesis of testosterone induced by hCG/LH (Frungieri et al. 2006).

It is therefore tempting to assume that, at least in hamster Leydig cells, there exists a regulatory loop in which testosterone induces COX2 expression and $\mathrm{PGF}_{2 \alpha}$ production. In turn, $\mathrm{PGF}_{2 \alpha}$ inhibits STAR and HSD17B1 expression and, consequently, testosterone production, thereby setting a brake on testicular steroidogenesis (Fig. 5; Frungieri et al. 2006, Matzkin et al. 2009).

In agreement with our findings in hamsters, it has been reported that $\mathrm{PGF}_{2 \alpha}$ reduced hCG-stimulated testosterone secretion in rat Leydig cells (Romanelli et al. 1995). Additionally, other authors (Saksena et al. 1973, Didolkar et al. 1981, Sawada et al. 1994) have shown that $\mathrm{PGF}_{2 \alpha}$ decreases plasma testosterone levels in male rats. On the contrary, injection of $\mathrm{PGF}_{2 \alpha}$ to male rhesus monkeys is followed by an abrupt rise in serum testosterone (Kimball et al. 1979).

Syntin et al. (2001) and Wang et al. (2005) have described that the COX2/PG system represents a

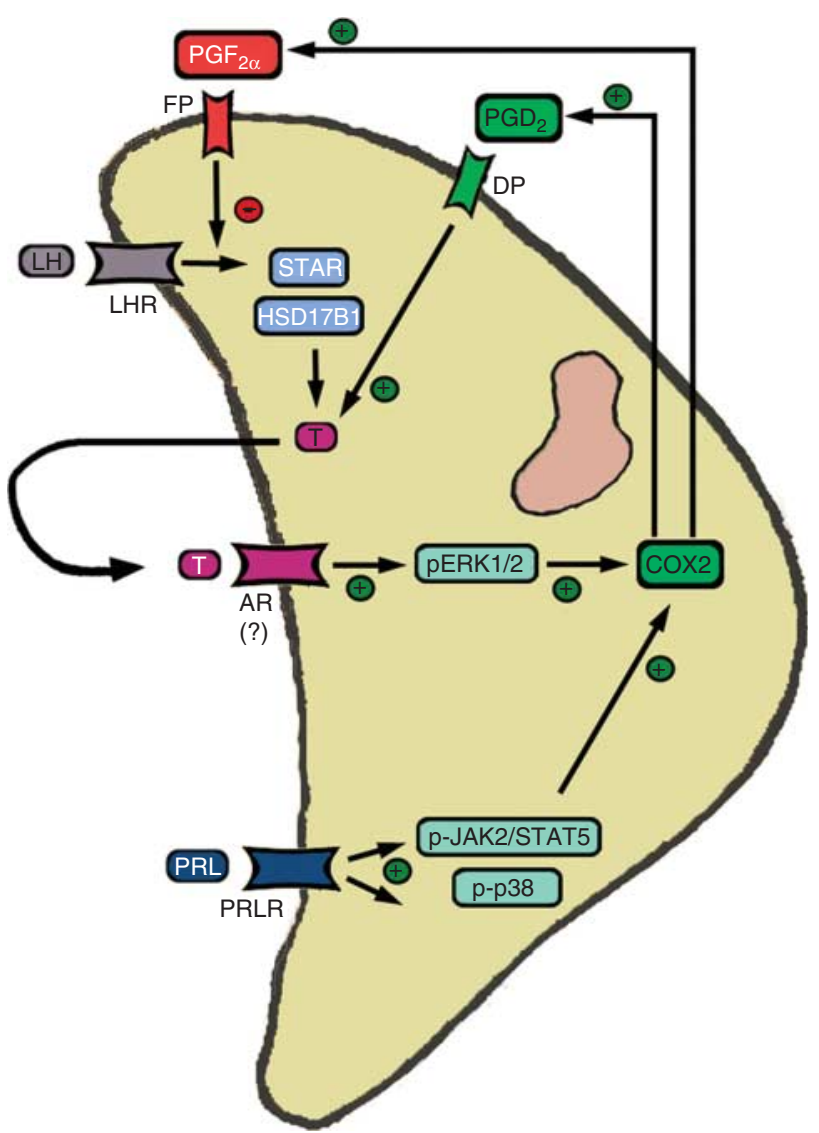

Figure 5 Summary view of COX2 expression/PG synthesis regulation, and the modulatory effect of some PGs on steroidogenesis in hamster Leydig cells. Based on experimental results, PRL induces COX2 expression as well as $\mathrm{PGD}_{2}$ and $\mathrm{PGF}_{2 \alpha}$ production in Leydig cells through activation of p38-MAPK and JAK2/STAT5. In addition, testosterone via androgen receptors (ARs) and a non-classical mechanism that involves phosphorylation of ERK1/2 also increases COX2 expression and PGs production. While $\mathrm{PGD}_{2}$ through DP receptors stimulates testosterone production under basal conditions, $\mathrm{PGF}_{2 \alpha}$ via FP receptors inhibits STAR and HSD17B1 expression and consequently testosterone production in the presence of $\mathrm{LH} / \mathrm{hCG}$, thus setting a brake on testicular steroidogenesis.

potential key factor in the age-related reduction in testosterone production, as up-regulation of COX2 expression in Brown Norway rats during aging is accompanied by decreased testicular production of testosterone. In this context, COX2 inhibition enhances steroidogenesis and Star gene expression in MA-10 mouse Leydig cells, whereas its overexpression leads to the opposite (Wang et al. 2003). Furthermore, production of testosterone by decapsulated mouse testes is significantly inhibited by adding some PGs $\left(\mathrm{PGA}_{1}\right.$, $\mathrm{PGA}_{2}$, and $\mathrm{PGE}_{1}$ ) to the incubation medium (Bartke et al. 1976). On the other hand, COX2 seems to be involved in aromatase post-translational activation and increased cell proliferation in the rat Leydig tumor cell line R2C (Sirianni et al. 2009).

From the aforementioned data, it is clear that Leydig cells express the inducible isoenzyme COX2 and produce 
PGs with age-, photoperiod-, and species-specific differences. In addition to its regulation by PRL and IL1 $\beta$, COX2 expression is also regulated by testosterone through a non-genomic mechanism. The existence of a COX2/PG system in Leydig cells serves as a local modulator of steroid hormone production.

\section{COX and PGs in Sertoli cells}

Spermatogenesis is dependent upon adequate Sertoli cell function (Griswold 1998). The expression of COX, production of $\mathrm{PGE}_{2}, \mathrm{PGF}_{2 \alpha}$, and $\mathrm{PGI}_{2}$, as well as the existence of the prostanoid receptors (i.e., EP1, EP2, EP3, EP4, IP, and FP) has been reported in Sertoli cells of immature and juvenile rodents (Ishikawa \& Morris 2006, Winnal et al. 2007, Kristensen et al. 2011).

Studies are usually limited to Sertoli cells isolated from immature rodents to avoid germ cell contamination during the purification procedure. Consequently, data obtained from adult Sertoli cells are scarce. As only Sertoli cells, spermatogonia, and a few primary spermatocytes are observed in testes of photoperiodically regressed adult Syrian hamsters (Fig. 4; Bartke 1985, Sinha Hikim et al. 1988, Rossi et al. 2014), this species becomes a useful and available experimental model for isolation of Sertoli cells from adult animals.

Follicle-stimulating hormone (FSH) and testosterone are the two major hormones that act in the testis to regulate spermatogenesis. Sertoli cells transduce signals from $\mathrm{FSH}$ and testosterone into the synthesis of factors that are required for spermatogenesis. These actions take place through $\mathrm{FSH}$ receptors and ARs located in Sertoli cells (Walker \& Cheng 2005, Matzkin et al. 2009, 2012a).

In recent studies carried out on Sertoli cells purified from testes of adult hamsters exposed to a short-day photoperiod, we have demonstrated that FSH exerts a stimulatory effect on COX2 expression, as well as on $15 \mathrm{~d}-\mathrm{PG} \mathrm{J}_{2}$ and $\mathrm{PGF}_{2 \alpha}$ production through a mechanism that involves ERK1/2 phosphorylation (Matzkin et al. 2012a). Supporting our results, Jannini et al. (1994) have shown FSH-stimulated eicosanoid generation dependent upon the activation of the COX pathway in immature rat Sertoli cells. Moreover, both stimulatory and inhibitory actions of $\mathrm{FSH}$ on ERK1/2 phosphorylation were described in rodent Sertoli cells (Crepieux et al. 2001, Meroni et al. 2004).

Testosterone also induces COX2 expression and increases $15 \mathrm{~d}-\mathrm{PG} \mathrm{J}_{2}$ production in adult hamster Sertoli cells via ARs most probably located on the cell surface (Matzkin et al. 2012a). The existence of testosteronebinding sites in the plasma membrane has been previously reported for Sertoli cells (Fix et al. 2004). Using the plasma membrane-impermeable testosteroneBSA, we observed that both COX2 expression and 15d$\mathrm{PGJ}_{2}$ production are enhanced in adult hamster Sertoli cells, via a non-classical androgen action associated with the activation of the ERK $1 / 2$ signaling pathway
(Matzkin et al. 2012a). Supporting these data, members of the MAPK pathway have been shown to form complexes with ARs on molecular scaffolds anchored to the plasma membrane (Pedram et al. 2007). Moreover, using an immunofluorescence technique, Cheng et al. (2007) have found that upon testosterone stimulation of rat Sertoli cells, a population of ARs is localized, in a transient manner, in the plasma membrane.

Among Sertoli cell functions that may be important to germ cell development is the provision of adequate levels of energy substrates such as lactate. In this context, the transport of glucose through the plasma membrane is the rate-limiting step in glucose metabolism and, consequently, in lactate production (Riera et al. 2001, 2009). Glucose enters the cell by carrier proteins called glucose transporters (known as GLUTs or SLC2A). Thus far, expression of SLC2A1, SLC2A3, and SLC2A8 transporters has been demonstrated in Sertoli cells (Carosa et al. 2005, Galardo et al. 2008). In adult hamster Sertoli cells, FSH and testosterone induce the uptake of $\left[2,6-{ }^{3} \mathrm{H}\right]$-2-deoxy-D-glucose, a non-metabolizable glucose analog. In accordance with these data, an increased FSH-mediated glucose uptake has been described in immature rat Sertoli cells (Riera et al. 2001).

The nuclear PPAR $\gamma$ receptor is present in hamster Sertoli cells (Matzkin et al. 2012a), suggesting a potential autocrine action of its natural ligand $15 \mathrm{~d}-\mathrm{PG}_{2}$. In fact, $15 \mathrm{~d}-\mathrm{PG} \mathrm{J}_{2}$ inhibits glucose uptake in adult hamster Sertoli cells via the nuclear PPAR $\gamma$ receptor (Matzkin et al. 2012a). The participation of arachidonic acid, precursor in PG biosynthesis, in the regulation of Sertoli cell function has recently been addressed (Meroni et al. 2004).

These results therefore have led to the suggestion that testosterone and $\mathrm{FSH}$ induce glucose uptake, COX2 expression, and $15 \mathrm{~d}-\mathrm{PGJ}_{2}$ production in Sertoli cells. Subsequently, $15 \mathrm{~d}-\mathrm{PGJ}_{2}$ acts via the nuclear PPAR $\gamma$ receptor to impair glucose entry. Therefore, the COX2/15d-PG) ${ }_{2} /$ PPAR $\gamma$ system may serve as a local autocrine modulator of Sertoli cell activity and, consequently, spermatogenic efficiency (Fig. 6).

Harmful actions of COX/PGs have also been described in Sertoli cells. Elevated testicular temperature in cryptorchidism decreases the expression of the cystic fibrosis transmembrane conductance regulator (CFTR), resulting in overexpression of COX2 and excessive $\mathrm{PGE}_{2}$ production in rodent Sertoli cells, which in turn lead to further damage of inter-Sertoli cell tight junctions and defective spermatogenesis (Chen et al. 2012). In contrast, toxic xenobiotics such as nonylphenol, commonly used as a detergent, up-regulate COX2 in TM4 immature mouse Sertoli cells (Liu et al. 2014).

In summary, Sertoli cells express COX2 and produce $\mathrm{PG}$ in response to $\mathrm{FSH}$ and a non-classical mechanism triggered by testosterone. PGs serve as local autocrine modulators of Sertoli cell function, and thus indirectly regulate sperm maturation. 


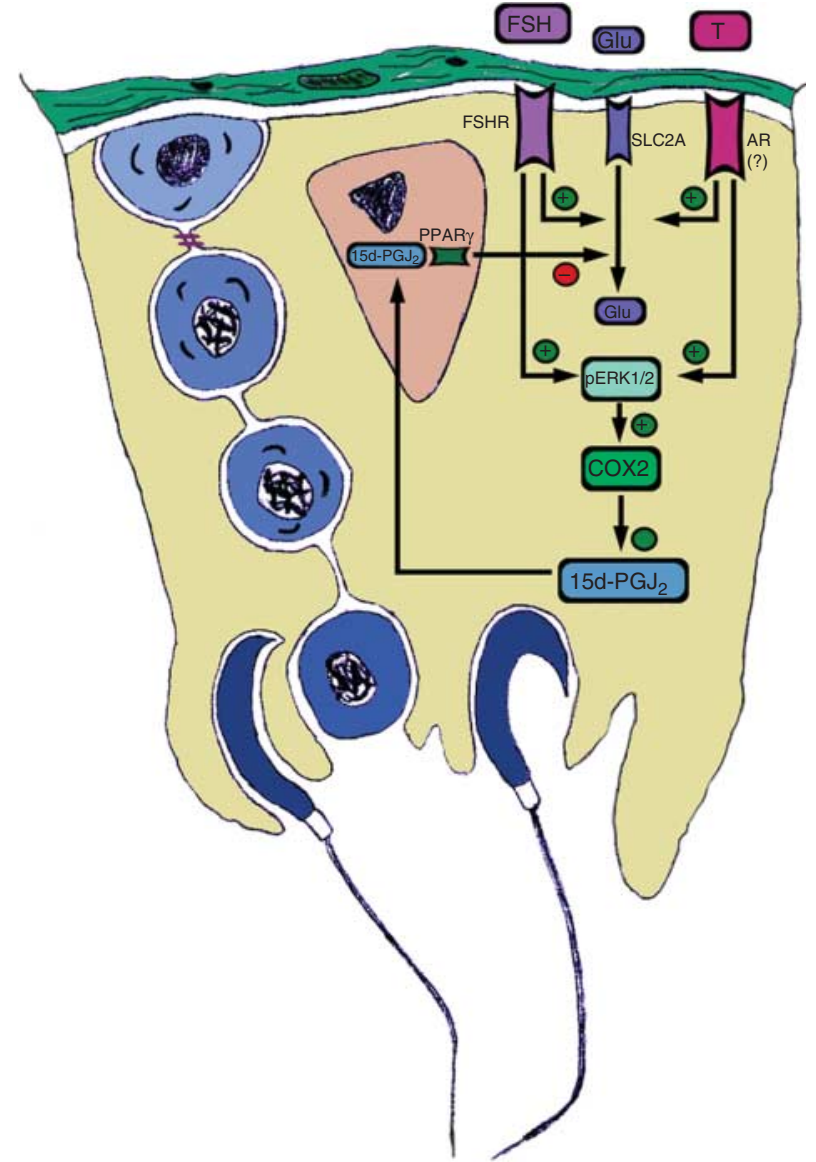

Figure 6 Summary view of COX2 expression/PGs production regulation, and the signaling pathway involved in the PG modulation of glucose uptake in Sertoli cells. Based on experimental results, testosterone exerts a stimulatory effect on COX2 expression and $15 \mathrm{~d}-\mathrm{PG}_{2}$ production in Sertoli cells through a non-classical mechanism that involves the presence of androgen receptors (ARs) and ERK1/2 activation. FSH also stimulated COX2/PGs via ERK1/2 phosphorylation. FSH and testosterone stimulate glucose uptake in Sertoli cells. Nevertheless, these hormones also exert an indirect negative regulation on glucose uptake, which involves the COX2/15d-PGJ $2 /$ PPAR $\gamma$ system.

\section{COX and PGs in the seminiferous tubule wall}

Depending on the species, the seminiferous tubule wall can be either a simple structure or a rather complex one. For instance, in rodents, the tubular wall is composed of a single cell layer and a tiny extracellular matrix. However, in the human testis, the seminiferous tubule wall is composed of the following components: an internal acellular basal membrane adjacent to the germinal epithelium containing collagen fibers, laminin, glycoproteins, and hyaluronic acid; a middle cellular zone made of spindle-shaped and contractile cells (called myoid cells or myofibroblasts); and an external cellular zone consisting of collagen-producing fibroblasts (Pop et al. 2011, Mayerhofer 2013). Disturbances in testicular function and decreased or no spermatogenic activity are associated with a thickening of the seminiferous tubule wall, which becomes fibrotically remodeled. Fibroblasts, together with smooth muscle cells, mediate tissue fibrosis and collagen deposition (Mayerhofer 2013). This frequent change is observed irrespective of the causes of male infertility and is regarded as a hallmark of male infertility (Frungieri et al. 2002a, Weinbauer et al. 2010). Different human cellular models have been used to study tubular fibrosis, the involvement of the local COX/PG system and its regulation. For instance, we used human fetal foreskin fibroblast cells (HFFF2), which show increased COX2 protein levels, PG $\left(\mathrm{PGF}_{2 \alpha}\right.$ and $\left.15 \mathrm{~d}-\mathrm{PG}_{2}\right)$ production, and cell proliferation in the presence of the serine protease tryptase (Frungieri et al. 2002a). Tryptase is a mast cell product known to cause proliferation of fibroblasts and fibrosis (Frungieri et al. 2002a). The effect of tryptase was tested in HFFF2 because increased numbers of tryptase-immunoreactive mast cells are detected in the seminiferous tubule wall in the testes of infertile men (Meineke et al. 2000). Furthermore, the amount of testicular tryptase-immunoreactive mast cells correlates with the fibrotic thickening of the tubular wall in patients with impaired spermatogenesis or Sertolicell-only (SCO) syndrome (Meineke et al. 2000). When the COX2 antagonist meloxicam was added to the incubation media, the proliferative action of the mast cell product tryptase on HFFF2 was blocked, implying that PGs derived from COX2 activity are crucially involved in this action. On the other hand, the nuclear PPAR $\gamma$ receptor is expressed in the seminiferous tubule wall of infertile patients as well as in HFFF2 cells, and its natural ligand $15 \mathrm{~d}-\mathrm{PGJ}_{2}$ directly increases fibroblast proliferation (Frungieri et al. 2002a). Thus, there is a signaling pathway linked to fibroblast proliferation that involves the mast cell product tryptase, its receptor PAR2, induction of COX2, synthesis of $15 \mathrm{~d}-\mathrm{PG}_{2}$, and its action through PPAR $\gamma$. The initial events of the tryptase/ PAR2 signaling pathway leading to COX2 induction and fibroblast proliferation involve up-regulation of the immediate-early genes C-JUN and C-FOS, and phosphorylation of ERK1/2 (Frungieri et al. 2005).

It is important to bear in mind that PAR2 receptors are expressed in interstitial cells, while PPAR $\gamma$ receptors are found in the peritubular cells of the human testis. Furthermore, mast cells containing tryptase accumulate in testes showing abnormal spermatogenesis, and COX2 is mostly detected in biopsies of patients with idiopathic infertility (Frungieri et al. 2002a). Thus, the fact that all components involved in the tryptase/COX2/15d-PGJ ${ }_{2} /$ PPAR $\gamma$-induced proliferation of HFFF2 cells are also present in the testes of infertile patients showing fibrotic thickening in the wall of the seminiferous tubules implies that COX2 and some PGs could be of relevance for human diseases linked to fibrotic disorders.

To further investigate the wall of the seminiferous tubules in health and disease, a new and more reliable experimental model has recently been developed. 
Human testicular peritubular cells were isolated from very small testicular tissue samples from adult patients with obstructive azoospermia but normal spermatogenesis (HTPCs), as well as from biopsies of men with non-obstructive azoospermia, impaired spermatogenesis, and testicular fibrosis (HTPCFs) (Albrecht et al. 2006, Schell et al. 2008, 2010, Spinnler et al. 2010, Mayerhofer 2013).

Tumor necrosis factor alpha (TNF $\alpha$ ), a cytokine with pleiotropic actions, which is known to be released from human testicular macrophages (Frungieri et al. 2002b), induces inflammatory markers in HTPCs such as COX2 and $\mathrm{PGD}_{2}$ (Schell et al. 2008). Previously, a $\mathrm{PGD}_{2}$ system had been identified in the human testis (Schell et al. 2007). This system includes the expression of $\mathrm{PGD}_{2}$ synthases and the existence of the prostanoid receptor DP in the testes of men suffering from spermatogenic damage and infertility (Schell et al. 2007).

On the other hand, $15 \mathrm{~d}-\mathrm{PGJ}_{2}$, via the generation of reactive oxygen species (ROS), strongly influences cultured HTPCs and HTPCFs (Kampfer et al. 2012). Upon $15 \mathrm{~d}-\mathrm{PGJ}_{2}$ treatment, cells become hypertrophic and show a diminished expression of smooth muscle cell markers (e.g., smooth muscle actin, MYH11, and calponin) as well as a reduced ability to contract. Interestingly, upon removal of $15 \mathrm{~d}-\mathrm{PGJ}_{2}$, cells spontaneously revert to the normal phenotype, an indication of a high intrinsic degree of cellular plasticity (Schell et al. 2010, Welter et al. 2013, Mayerhofer 2013). HTPCFs express higher levels of the $\mathrm{H}_{2} \mathrm{O}_{2}$-metabolizing enzyme catalase than HTPCs, circumstantial evidence for increased ROS levels in the tubular wall of infertility patients (Kampfer et al. 2012). Thus, it is possible to speculate that up-regulation of $\mathrm{COX} 2 / 15 \mathrm{~d}-\mathrm{PGJ}_{2}$ and generation of ROS are interconnected events, forcing smooth muscle-like peritubular cells to adapt and change their phenotype, and finally, to lose contractility (Mayerhofer 2013). As contractility of the tubular wall is crucial for sperm transport and fertility, COX2/15d-PGJ ${ }_{2}$ could be, to date, an overlooked factor that contributes to male infertility.

Hence, results obtained from cellular studies and parallel examinations of human testicular biopsies provide insights into the roles played by PGs in tubular fibrosis and contractility. Consequently, PGs may be crucial factors for the active transportation of immotile sperm that takes place in the seminiferous tubules. Furthermore, these bioactive lipid substances might be key players in the paracrine interactions taking place between peritubular cells and other testicular somatic cells such as Leydig and Sertoli cells.

\section{COX and PGs in testicular immune cells}

The testis is one of a small number of so-called immunologically privileged tissues of the body. In fact, the production, differentiation, and presence of germ cells represent inimitable challenges to the immune system, because these cells appear long after the maturation of the immune system and formation of systemic self-tolerance (Fijak \& Meinhardt 2006). The blood-testis barrier represents an essential element for local immunosuppression. However, the existence of the blood-testis barrier does not mean that the lymphatic drainage of the testis is deficient or that immune cells are unable to access germ cells (Hedger 2002). Actually, immune cells are observed in the capsule, interstitium, and seminiferous tubules of the testis. In particular, large numbers of macrophages are found in the testis. Significant amounts of testicular mast cells, dendritic cells, as well as effector, regulatory, and natural killer T lymphocytes have also been reported (Itoh et al. 1995, Tompkins et al. 1998, Meineke et al. 2000, Frungieri et al. 2002b, Hedger 2002, Jacobo et al. 2009).

Testicular immunoregulation depends on a delicate equilibrium between immunoprivilege and inflammation in which immune cells play a dual role. Under physiological conditions, antigen-specific autoimmune responses are prevented by systemic and local tolerance mechanisms involving the actions of dendritic cells and regulatory T lymphocytes, as well as immunosuppressor cytokines mainly secreted by resident macrophages. Breakdown of immune homeostasis in the testis leads to inflammation (Pérez et al. 2013). It is known that male genital tract inflammations are relevant co-factors in infertility. Human testicular macrophages from infertile patients secrete pro-inflammatory cytokines such as IL1 $\beta$ and TNF $\alpha$ (Frungieri et al. 2002b). The numbers of macrophages and mast cells are markedly increased in testes of patients, indicating impaired spermatogenesis (Meineke et al. 2000, Frungieri et al. 2002b). Furthermore, the distribution pattern and morphology of these immune cells are altered in pathological states. For instance, there is a significant shift in the location of macrophages and mast cells from the interstitium to the tubular compartment in the testes of infertile men (Meineke et al. 2000, Frungieri et al. 2002b). In samples with normal spermatogenesis, these immune cells are round and located mainly in the interstitial spaces close to Leydig cells. In pathological conditions, mast cells and macrophages are heterogeneous, with not only rounded but also elongated shapes and signs of degranulation (Meineke et al. 2000, Frungieri et al. 2002b). In contrast to men, it has been described that mast cells are located almost exclusively in the capsule adjacent to testicular blood vessels in the testes of rodents, including hamsters (Frungieri et al. 1999, Rossi et al. 2014).

COX2 is expressed in both testicular mast cells and macrophages of patients suffering from hypospermatogenesis, germ cell arrest, mixed atrophy, or SCO syndrome (Matzkin et al. 2010, Welter et al. 2011, Rossi et al. 2014). Interestingly, few mast cells that do not express COX2 are observed in testes with normal spermatogenesis 
(Welter et al. 2011). Human testicular macrophages secrete IL1 $\beta$, and a positive correlation between IL1 $\beta$ levels and COX2 expression has been described in the testes of infertile patients (Matzkin et al. 2010).

Thus, mast cells and macrophages increased the population number and secretion of pro-inflammatory cytokines, as well as the acquisition of the capability to produce PG inflammatory mediators seem to play a decisive role in the autoimmune basis of testicular inflammation associated with subfertility and infertility.

\section{Concluding remarks and future perspectives}

In contraposition to initial data showing that fertility is not affected in Cox-deficient male mice (Langenbach et al. 1999), and therefore that PGs might not be significant to testicular function, research carried out in recent years describes a plethora of PG functions in the male gonad.

A COX2/PG system has been described in the two key somatic cell types of the testis: Leydig and Sertoli cells. Furthermore, studies have provided new insights into how several hormones and cytokines (i.e., FSH, PRL, testosterone, and IL1 $\beta$ ) modulate COX2 expression and PG production in Leydig and Sertoli cells. Studies performed mainly in rodents indicate that some PGs (i.e., $\mathrm{PGD}_{2}$ and $\mathrm{PGF}_{2 \alpha}$ ) modulate androgen production in Leydig cells, while $15 \mathrm{~d}-\mathrm{PG}_{2}$ regulates glucose transport in Sertoli cells and, consequently, spermatogenic efficiency. Recently, an additional physiological role of COX2 as a protector of germ cells against spermatogenic disturbance has been reported in an experimental cryptorchidism mouse model (Kubota et al. 2011).

Most importantly, besides their action on testicular physiology, PGs seem to be associated with pathogenesis or maintenance of infertility states in men.

For instance, $15 \mathrm{~d}-\mathrm{PGJ}_{2}$ was associated with the fibrosis and loss of contractility often observed in the wall of the seminiferous tubules in patients suffering from idiopathic infertility. Furthermore, the existence of a COX2/PG system in testicular immune cells (mast cells and macrophages), showing a significant increase in their population number in some pathologies, strongly suggests the importance of PGs in the development of local inflammation that might further compromise testicular function in patients with hypospermatogenesis, germ cell arrest, or SCO syndrome.

Currently, the majority of infertile men present disorders either untreatable or treatable with drugs of questionable effectiveness. In this context, drugs targeting COX, PGs, and prostanoid receptors are being developed or used in clinical practice for a variety of conditions. For example, there are widely marketed and relatively safe drugs such as celecoxib, valdecoxib, and rofecoxib, developed for specific COX2 inhibition, that possess all of the analgesic, antipyretic, and anti-inflammatory activities of the older nonselective NSAIDs (Simmons et al. 2004).

Therefore, the study of COX and PG actions appears to be a promising field of research with a potential impact on male fertility. Further advances in the knowledge of the role played by COX, PGs, and their receptors in the human testis, as well as future investigations concerning the impact of drugs targeting COX/PGs at the testicular level, could lead to new therapeutic approaches in idiopathic male infertility. In this context, non-selective inhibitors of COX usually used as mild analgesics, such as indomethacin, paracetamol, and aspirin, have been shown to display endocrine-disrupting properties in the adult human testis in vitro (Albert et al. 2013). Nevertheless, the beneficial or disadvantageous effects of specific COX2 inhibitors in the infertile human testis have not, to date, been fully explored.

\section{Declaration of interest}

The authors declare that there is no conflict of interest that could be perceived as prejudicing the impartiality of the review.

\section{Funding}

Studies mentioned in this review were supported by grants from Consejo Nacional de Investigaciones Científicas y Técnicas (CONICET), Agencia Nacional de Promoción Científica y Técnica (ANPCyT), Ministerio de Ciencia, Tecnología e Innovación Productiva (MINCYT), Facultad de MedicinaUniversidad de Buenos Aires, Fundación Antorchas, and Fundación Alberto J. Roemmers of Argentina, and Deutscher Akademischer Austausch Dienst (DAAD) and Deutsche Forschungsgemeinschaft (DFG) of Germany, especially MA1080/21-1 and MA1080/25-1.

\section{Acknowledgements}

The authors are grateful to our colleagues, Drs $\mathrm{V}$ Ambao, S Campo, M H Carino, S B Cigorraga, B Gonzalez, C R Gonzalez, L González, S I Gonzalez-Calvar, O Levalle, L Lustig, F Parborell, E H Pellizarri, P Pomata, R Ponzio, E Puigdomenech, S P Rossi, C Terradas and D Turyn (Buenos Aires, Argentina), and Drs M Albrecht, B Jessberger, C Kampfer, F M Köhn, C Mayer, $\checkmark$ Meineke, R Raemsch, C Schell, J U Schwarzer, S Spillner, K Spinnler, H-J Vogt, S Weidinger, and S Windschuettl (Munich, Germany).

\section{References}

Albert O, Desdoits-Lethimonier C, Lesné L, Legrand A, Guillé F, Bensalah K, Dejucq-Rainsford N \& Jégou B 2013 Paracetamol, aspirin and indomethacin display endocrine disrupting properties in the adult human testis in vitro. Human Reproduction 28 1890-1898. (doi:10. 1093/humrep/det112)

Albrecht M, Ramsch R, Kohn FM, Schwarzer JU \& Mayerhofer A 2006 Isolation and cultivation of human testicular peritubular cells: a new 
model for the investigation of fibrotic processes in the human testis and male infertility. Journal of Clinical Endocrinology and Metabolism 91 1956-1960. (doi:10.1210/jc.2005-2169)

Balaji T, Ramanathan M \& Padmanabhan Menon V 2007 Localization of cyclooxygenase- 2 in mice testis and assessment of its possible role through suppressing its expression using nimesulide: a preferential cyclooxygenase-2 inhibitor. Prostaglandins, Leukotrienes, and Essential Fatty Acids 76 341-348. (doi:10.1016/j.plefa.2007.04.006)

Bartke A 1985 Male hamster reproductive endocrinology. In The Hamster, pp 78-98. Ed. HI Spiegel. New York: Plenum Publishing Corp.

Bartke A, Kupfer D \& Dalterio S 1976 Prostaglandins inhibit testosterone secretion by mouse testes in vitro. Steroids 28 81-88. (doi:10.1016/ 0039-128X(76)90127-6)

Carosa E, Radico C, Giansante N, Rossi S, D'Adamo F, Di Stasi SM, Lenzi A \& Jannini EA 2005 Ontogenetic profile and thyroid hormone regulation of type- 1 and type- 8 glucose transporters in rat Sertoli cells. International Journal of Andrology 28 99-106. (doi:10.1111/j.1365-2605.2005. 00516.x)

Chen J, Fok KL, Chen H, Zhang XH, Xu WM \& Chan HC 2012 Cryptorchidism-induced CFTR down-regulation results in disruption of

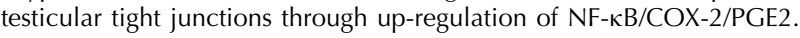
Human Reproduction 27 2585-2597. (doi:10.1093/humrep/des254)

Cheng J, Watkins SC \& Walker W 2007 Testosterone activates mitogenactivated protein kinase via Src kinase and the epidermal growth factor receptor in Sertoli cells. Endocrinology 148 2066-2074. (doi:10.1210/ en.2006-1465)

Crepieux P, Marion S, Martinat N, Fafeur V, Vern YL, Kerboeuf D, Guillou F \& Reiter E 2001 The ERK-dependent signalling is stage specifically modulated by FSH, during primary Sertoli cell maturation. Oncogene 20 4696-4709. (doi:10.1038/sj.onc.1204632)

Didolkar AK, Gurjar A, Joshi UM, Sheth AR \& Roychowdhury D 1981 Effect of prostaglandins A-1, E-2 and F-2 $\alpha$ on blood plasma levels of testosterone, LH and FSH in male rats. Andrologia 13 50-55. (doi:10.1111/j.1439-0272.1981.tb00008.x)

von Euler US 1935 The specific blood pressure lowering substance in human prostate and seminal vesicle secretions. Klinische Wochenschrift 14 1182-1183. (doi:10.1007/BF01778029)

Fijak M \& Meinhardt A 2006 The testis in immune privilege. Immunological Reviews 213 66-81. (doi:10.1111/j.1600-065X.2006.00438.x)

Fix C, Jordan C, Cano P \& Walker WH 2004 Testosterone activates mitogen activated protein kinase and the cAMP response element binding protein transcription factor in Sertoli cells. PNAS 101 110919-110924. (doi:10.1073/pnas.0404278101)

Foradori CD, Weiser MJ \& Handa RJ 2008 Non-genomic actions of androgens. Frontiers in Neuroendocrinology 29 169-181. (doi:10.1016/ j.yfrne.2007.10.005)

Frungieri MB, Gonzalez-Calvar SI, Rubio M, Ozu M, Lustig L \& Calandra RS 1999 Serotonin in golden hamster testes: testicular levels, immunolocalization, and role during sexual development and photoperiodic regression-recrudescence transition. Neuroendocrinology 69 299-308. (doi:10.1159/000054431)

Frungieri MB, Weidinger SV, Meineke V, Köhn FM \& Mayerhofer A 2002a Proliferative action of mast-cell tryptase is mediated by PAR2, COX2, prostaglandins, and PPAR $\gamma$ : possible relevance to human fibrotic disorders. PNAS 99 15072-15077. (doi:10.1073/pnas. 232422999)

Frungieri MB, Calandra RS, Lustig L, Meineke V, Köhn FM, Vogt HJ \& Mayerhofer A 2002 $b$ Number, distribution pattern, and identification of macrophages in the testes of infertile men. Fertility and Sterility $\mathbf{7 8}$ 298-306. (doi:10.1016/S0015-0282(02)03206-5)

Frungieri MB, Albrecht M, Raemsch R \& Mayerhofer A 2005 The action of the mast cell product tryptase on cyclooxygenase-2 (COX2) and subsequent fibroblast proliferation involves activation of the extracellular signal-regulated kinase isoforms 1 and 2 (erk1/2). Cellular Signalling 17 525-533. (doi:10.1016/j.cellsig.2004.09.017)

Frungieri MB, Gonzalez-Calvar SI, Parborell F, Albrecht M, Mayerhofer A \& Calandra RS 2006 Cyclooxygenase-2 and prostaglandin F2 $\alpha$ in Syrian hamster Leydig cells: inhibitory role on luteinizing hormone/ human chorionic gonadotropin-stimulated testosterone production. Endocrinology 147 4476-4485. (doi:10.1210/en.2006-0090)

Galardo MN, Riera MF, Pellizzari EH, Chemes HE, Venara MC, Cigorraga SB \& Meroni SB 2008 Regulation of expression of Sertoli cell glucose transporters 1 and 3 by FSH, IL1 $\beta$, and bFGF at two different time-points in pubertal development. Cell and Tissue Research 334 295-304. (doi:10.1007/s00441-008-0656-y)

Goldblatt MW 1933 A depressor substance in seminal fluid. Journal of the Society of Chemical Industry 52 1056-1057.

Griswold MD 1998 The central role of Sertoli cells in spermatogenesis. Seminars in Cell \& Developmental Biology 9 411-416. (doi:10.1006/ scdb.1998.0203)

Harnett MM \& Goodrigde HS 2005 Membrane receptors and signal transduction. In Medical Biochemistry, p 555.Eds JW Baynes\& MH Dominiczak. London: Elsevier Mosby.

Harris RE 2009 Cyclooxygenase-2 (cox-2) blockade in the chemoprevention of cancers of the colon, breast, prostate, and lung. Inflammopharmacology 17 55-67. (doi:10.1007/s10787-009-8049-8)

Hase T, Yoshimura R, Matsuyama M, Kawahito Y, Wada S, Tsuchida K, Sano H \& Nakatani T 2003 Cyclooxygenase-1 and -2 in human testicular tumours. European Journal of Cancer 39 2043-2049. (doi:10.1016/ S0959-8049(03)00485-4)

Hedger MP 2002 Macrophages and the immune responsiveness of the testis. Journal of Reproductive Immunology 57 19-34. (doi:10.1016/ S0165-0378(02)00016-5)

Ishikawa T \& Morris PL 2006 A multistep kinase-based Sertoli cell autocrine amplifying loop regulates prostaglandins, their receptors, and cytokines. Endocrinology 147 1706-1716. (doi:10.1210/en.2005-1576)

Itoh M, De Rooij DG, Jansen A \& Drexhage HA 1995 Phenotypical heterogeneity of testicular macrophages/dendritic cells in normal adult mice: an immunohistochemical study. Journal of Reproductive Immunology 28 217-232. (doi:10.1016/0165-0378(95)00923-9)

Jacobo P, Guazzone VA, Jarazo-Dietrich S, Theas MS \& Lustig L 2009 Differential changes in $\mathrm{CD} 4+$ and $\mathrm{CD} 8+$ effector and regulatory $\mathrm{T}$ lymphocyte subsets in the testis of rats undergoing autoimmune orchitis. Journal of Reproductive Immunology 81 44-54. (doi:10.1016/j. jri.2009.04.005)

Jannini EA, Ulisse S, Cecconi S, Cironi L, Colonna R, D'Armiento M, Santoni A \& Cifone MG 1994 Follicle-stimulating hormone-induced phospholipase A2 activity and eicosanoid generation in rat Sertoli cells. Biology of Reproduction 51 140-145. (doi:10.1095/biolreprod51.1.140)

Kampfer C, Spillner S, Spinnler K, Schwarzer JU, Terradas C, Ponzio R, Puigdomenech E, Levalle O, Köhn FM, Matzkin ME et al. 2012 Evidence for an adaptation in ROS scavenging systems in human peritubular testicular cells from infertility patients. International Journal of Andrology 35 793-801. (doi:10.1111/j.1365-2605.2012.01281.x)

Katori M \& Majima M 2000 Cyclooxygenase-2 its rich diversity of roles and possible application of its selective inhibitors. Inflammation Research 49 367-392. (doi:10.1007/s000110050605)

Kelly RW 1978 Prostaglandins in semen; their occurrence and possible physiological significance. International Journal of Andrology $\mathbf{1}$ 188-200. (doi:10.1111/j.1365-2605.1978.tb00591.x)

Kimball FA, Kirton KT, Forbes AD, Frielink RD, Porteus SE, Wilks JW, Mohberg NR \& Turner LF 1979 Serum FSH, LH and testosterone in the male rhesus following prostaglandin injection. Prostaglandins $\mathbf{1 8}$ 117-126. (doi:10.1016/S0090-6980(79)80029-5)

Kowalewski MP, Dyson MT, Manna PR \& Stocco DM 2009 Involvement of peroxisome proliferator-activated receptor gamma in gonadal steroidogenesis and steroidogenic acute regulatory protein expression. Reproduction, Fertility, and Development 21 909-922. (doi:10.1071/ RD09027)

Kristensen DM, Skalkam ML, Audouze K, Lesné L, Desdoits-Lethimonier C, Frederiksen H, Brunak S, Skakkebæk NE, Jégou B, Hansen JB et al. 2011 Many putative endocrine disruptors inhibit prostaglandin synthesis. Environmental Health Perspectives 119 534-541. (doi:10.1289/ehp. 1002635)

Kubota H, Sasaki S, Kubota Y, Umemoto Y, Yanai Y, Tozawa K, Hayashi Y \& Kohri K 2011 Cyclooxygenase-2 protects germ cells against spermatogenesis disturbance in experimental cryptorchidism model mice. Journal of Andrology 32 77-85. (doi:10.2164/jandrol.109.008888)

Langenbach R, Loftin CD, Lee C \& Tiano H 1999 Cyclooxygenase-deficient mice. A summary of their characteristics and susceptibilities to inflammation and carcinogenesis. Annals of the New York Academy of Sciences 889 52-61. (doi:10.1111/j.1749-6632.1999.tb08723.x) 
Lincoln G 2000 Melatonin after four decades. In Systems Ancient and Modern, pp 137-151. Ed. J Olcese. New York: Klumer Academic/ Plenum.

Liu X, Nie S, Huang D \& Xie M 2009 Nonylphenol regulates cyclooxygenase-2 expression via Ros-activated NF- $\kappa$ B pathway in sertoli TM4 cells. Environmental Toxicology 119 368-380. (doi:10.1213/ANE. 0000000000000303)

Matzkin ME, Gonzalez-Calvar SI, Mayerhofer A, Calandra RS \& Frungieri MB 2009 Testosterone induction of prostaglandin-endoperoxide synthase 2 expression and prostaglandin F2 $\alpha$ production in hamster Leydig cells. Reproduction 138 163-175. (doi:10.1530/REP-09-0023)

Matzkin ME, Mayerhofer A, Rossi SP, Gonzalez B, Gonzalez CR, GonzalezCalvar SI, Terradas C, Ponzio R, Puigdomenech E, Levalle O et al. 2010 Cyclooxygenase-2 (COX-2) in testes of infertile men: evidence for the induction of prostaglandins (PGs) synthesis by interleukin-1 $\beta$ (IL-1 $\beta$ ). Fertility and Sterility 94 1933-1936. (doi:10.1016/j.fertnstert.2010. 01.039)

Matzkin ME, Pellizzari EH, Rossi SP, Calandra RS, Cigorraga SB \& Frungieri MB 2012a Exploring the cyclooxygenase 2 (COX2)/ $15 \mathrm{~d}-\Delta 12,14 \mathrm{PG} 2 \mathrm{2}$ system in hamster Sertoli cells: regulation by $\mathrm{FSH} /$ testosterone and relevance to glucose uptake. General and Comparative Endocrinology 179 254-264. (doi:10.1016/j.ygcen.2012.08.020)

Matzkin ME, Ambao V, Carino MH, Rossi SP, González L, Turyn D, Campo S, Calandra RS \& Frungieri MB 2012b Prolactin (PRL) induction of cyclooxygenase 2 (COX2) expression and prostaglandin (PG) production in hamster Leydig cells. Molecular and Cellular Endocrinology 348 33-46. (doi:10.1016/j.mce.2011.07.029)

Mayerhofer A 2013 Human testicular peritubular cells: more than meets the eye. Reproduction 145 R107-R116. (doi:10.1530/REP-12-0497)

Mazaud-Guittot S, Nicolas Nicolaz C, Desdoits-Lethimonier C, Coiffec I, Ben Maamar M, Balaguer P, Kristensen DM, Chevrier C, Lavoué V, Poulain P et al. 2013 Paracetamol, aspirin, and indomethacin induce endocrine disturbances in the human fetal testis capable of interfering with testicular descent. Journal of Clinical Endocrinology and Metabolism 98 E1757-E1767. (doi:10.1210/jc.2013-2531)

Meineke V, Frungieri MB, Jessberger B, Vogt H \& Mayerhofer A 2000 Human testicular mast cells contain tryptase: increased mast cell number and altered distribution in the testes of infertile men. Fertility and Sterility 74 239-244. (doi:10.1016/S0015-0282(00)00626-9)

Meroni SB, Riera MF, Pellizzari EH, Galardo MN \& Cigorraga SB 2004 FSH activates phosphatidylinositol 3-kinase/protein kinase B signaling pathway in 20-day-old Sertoli cells independently of IGF-I. Journal of Endocrinology 180 257-265. (doi:10.1677/joe.0.1800257)

Moniot B, Ujjan S, Champagne J, Hirai H, Aritake K, Nagata K, Dubois E, Nidelet S, Nakamura M, Urade Y et al. 2014 Prostaglandin D2 acts through the Dp2 receptor to influence male germ cell differentiation in the foetal mouse testis. Development 141 3561-3571. (doi:10.1242/dev. 103408)

Narumiya S 2007 Physiology and pathophysiology of prostanoid receptors. Proceedings of the Japan Academy. Series B, Physical and Biological Sciences 83 296-319. (doi:10.2183/pjab.83.296)

Oduru S, Campbell JL, Karri S, Hendry WJ, Khan SA \& Williams SC 2003 Gene discovery in the hamster: a comparative genomics approach for gene annotation by sequencing of hamster testis CDNAs. BMC Genomics 4 22. (doi:10.1186/1471-2164-4-22)

O'Shaughnessy PJ, Johnston H, Willerton L \& Baker PJ 2002 Failure of normal adult Leydig cell development in androgen-receptor-deficient mice. Journal of Cell Science 115 3491-3496.

Pandey AK, Yin X, Schiffer RB, Hutson JC, Stocco DM, Grammas P \& Wang X 2009 Involvement of the thromboxane A2 receptor in the regulation of steroidogenic acute regulatory gene expression in murine Leydig cells. Endocrinology 150 3267-3273. (doi:10.1210/en.2008-1425)

Parillo F, Catone G, Boiti C \& Zerani M 2011 Immunopresence and enzymatic activity of nitric oxide synthases, cyclooxygenases and PGE29-ketoreductase and in vitro production of PGF2 $\alpha$, PGE2 and testosterone in the testis of adult and prepubertal alpaca (Lama pacos). General and Comparative Endocrinology 171 381-388. (doi:10.1016/ j.ygcen.2011.03.001)

Pedram A, Razandi M, Sainson RC, Kim JK, Hughes CC \& Levin ER 2007 A conserved mechanism for steroid receptor translocation to the plasma membrane. Journal of Biological Chemistry 282 22278-22288. (doi:10. 1074/jbc.M611877200)
Pérez CV, Theas MS, Jacobo PV, Jarazo-Dietrich S, Guazzone VA \& Lustig L 2013 Dual role of immune cells in the testis: protective or pathogenic for germ cells? Spermatogenesis 3 e23870. (doi:10.4161/spmg.23870)

Pop OT, Cotoi CG, Pleşea IE, Gherghiceanu M, Enache SD, Mandache E, Hortopan G \& Pleşea RM 2011 Histological and ultrastructural analysis of the seminiferous tubule wall in ageing testis. Romanian Journal of Morphology and Embryology 52 (1 Suppl) 241-248.

Riera MF, Meroni SB, Gómez GE, Schteingart HF, Pellizzari EH \& Cigorraga SB 2001 Regulation of lactate production by FSH, IL1 $\beta$, and TNF $\alpha$ in rat Sertoli cells. General and Comparative Endocrinology 122 88-97. (doi:10.1006/gcen.2001.7619)

Riera MF, Galardo MN, Pellizzari EH, Meroni SB \& Cigorraga SB 2009 Molecular mechanisms involved in Sertoli cell adaptation to glucose deprivation. American Journal of Physiology. Endocrinology and Metabolism 297 E907-E914. (doi:10.1152/ajpendo.00235.2009)

Romanelli F, Valenca M, Conte D, Isidori A \& Negro-Vilar A 1995 Arachidonic acid and its metabolites effects on testosterone production by rat Leydig cells. Journal of Endocrinological Investigation 18 186-193. (doi:10.1007/BF03347801)

Rossi SP, Windschuettl S, Matzkin ME, Terradas C, Ponzio R, Puigdomenech E, Levalle O, Calandra RS, Mayerhofer A \& Frungieri MB 2014 Melatonin in testes of infertile men: evidence for anti-proliferative and anti-oxidant effects on local macrophage and mast cell populations. Andrology 2 436-449. (doi:10.1111/j.2047-2927. 2014.00207.x)

Rossitto M, Ujjan S, Poulat F \& Boizet-Bonhoure B 2015 Multiples roles of the prostaglandin D2 signaling pathway in reproduction. Reproduction 149 R49-R58. (doi:10.1530/REP-14-0381)

Saksena SK, el-Safoury S \& Bartke A 1973 Prostaglandins E2 and F2 decrease plasma testosterone levels in male rats. Prostaglandins 4 235-242. (doi:10.1016/0090-6980(73)90041-5)

Santoro M, Guido C, De Amicis F, Sisci D, Vizza D, Gervasi S, Carpino A \& Aquila S 2013 Sperm metabolism in pigs: a role for peroxisome proliferator-activated receptor gamma (PPAR $\gamma$ ). Journal of Experimental Biology 216 1085-1092. (doi:10.1242/jeb.079327)

Sawada T, Asada M \& Mori J 1994 Effects of single and repeated administration of prostaglandin F2 $\alpha$ on secretion of testosterone by male rats. Prostaglandins 47 345-352. (doi:10.1016/0090-6980(94) 90052-3)

Schaefer M, Hofmann T, Schultz G \& Gudermann T 1998 A new prostaglandin $\mathrm{E}$ receptor mediates calcium influx and acrosome reaction in human spermatozoa. PNAS 95 3008-3013. (doi:10.1073/pnas.95.6. 3008)

Schell C, Frungieri MB, Albrecht M, Gonzalez-Calvar SI, Kohn FM, Calandra RS \& Mayerhofer A 2007 A prostaglandin D2 system in the human testis. Fertility and Sterility $\mathbf{8 8}$ 233-236. (doi:10.1016/j.fertnstert. 2006.11.100)

Schell C, Albrecht A, Mayer C, Schwarzer JU, Frungieri MB \& Mayerhofer A 2008 Exploring human testicular peritubular cells: identification of secretory products and regulation by TNF $\alpha$. Endocrinology 149 1678-1686. (doi:10.1210/en.2007-1064)

Schell C, Albrecht M, Spillner S, Mayer C, Kunz L, Kohn FM, Schwarzer U \& Mayerhofer A 2010 15-Deoxy- $\Delta$ 12-14-prostaglandin-J2 induces hypertrophy and loss of contractility in human testicular peritubular cells: implications for human male fertility. Endocrinology 151 1257-1268. (doi:10.1210/en.2009-1325)

Simmons DL, Botting RM \& Hla T 2004 Cyclooxygenase isozymes: the biology of prostaglandin synthesis and inhibition. Pharmacological Reviews 56 387-437. (doi:10.1124/pr.56.3.3)

Sinha YN 1992 Prolactin variants. Trends in Endocrinology and Metabolism 3 100-106. (doi:10.1016/1043-2760(92)90021-R)

Sinha Hikim AP, Bartke A \& Russell LD 1988 The seasonal breeding hamster as a model to study structure function relationships in the testis. Tissue \& Cell 20 63-78. (doi:10.1016/0040-8166(88)90008-0)

Sirianni R, Chimento A, De Luca A, Zolea F, Carpino A, Rago V, Maggiolini M, Ando S \& Pezzi V 2009 Inhibition of cyclooxygenase-2 down-regulates aromatase activity and decreases proliferation of Leydig tumor cells. Journal of Biological Chemistry 284 28905-28916. (doi:10. 1074/jbc.M109.041020)

Smith WL \& Langenbach R 2001 Why there are two cyclooxygenase isozymes. Journal of Clinical Investigation 107 1491-1495. (doi:10. 1172/JCl13271) 
Spinnler K, Köhn FM, Schwarzer U \& Mayerhofer A 2010 Glial cell linederived neurotrophic factor is constitutively produced by human testicular peritubular cells and may contribute to the spermatogonial stem cell niche in man. Human Reproduction 25 2181-2187. (doi:10. 1093/humrep/deq170)

Syntin P, Chen H, Zirkin BR \& Robaire B 2001 Gene expression in Brown Norway rat Leydig cells: effects of age and of age-related germ cell loss. Endocrinology 142 5277-5285. (doi:10.1210/endo.142.12.8526)

Thibodeau GA \& Patton KT 2012 The reproductive systems. In Structure \& Function of the Body, 14th edn, Eds. GA Thibodeau \& KT Patton. pp 447-448. St Louis, MO: Mosby Elsevier.

Tokugawa Y, Kunishige I, Kubota Y, Shimoya K, Nobunaga T, Kimura T, Saji F, Murata Y, Eguchi N, Oda H et al. 1998 Lipocalin-type prostaglandin $\mathrm{D}$ synthase in human male reproductive organs and seminal plasma. Biology of Reproduction 58 600-607. (doi:10.1095/ biolreprod58.2.600)

Tompkins AB, Hutchinson P, de Kretser DM \& Hedger MP 1998 Characterization of lymphocytes in the adult rat testis by flow cytometry: effects of activin and transforming growth factor beta on lymphocyte subsets in vitro. Biology of Reproduction 58 943-951. (doi:10.1095/ biolreprod58.4.943)

Walch L, Clavarino E \& Morris PL 2003 Prostaglandin (PG) FP and EP1 receptors mediate PGF2 $\alpha$ and PGE2 regulation of interleukin-1 $\beta$ expression in Leydig cell progenitors. Endocrinology 144 1284-1291. (doi:10.1210/en.2002-220868)

Walker WH \& Cheng J 2005 FSH and testosterone signaling in Sertoli cells. Reproduction 130 15-28. (doi:10.1530/rep.1.00358)

Wang X, Dyson MT, Jo Y \& Stocco DM 2003 Inhibition of cyclooxygenase-2 activity enhances steroidogenesis and steroidogenic acute regulatory gene expression in MA-10 mouse Leydig cells. Endocrinology 144 3368-3375. (doi:10.1210/en.2002-0081)
Wang X, Shen Ch-L, Dyson MT, Eirmerl S, Orly J, Hutson JC \& Stocco DM 2005 Cyclooxygenase-2 regulation of the age-related decline in testosterone biosynthesis. Endocrinology 146 4202-4208. (doi:10. 1210/en.2005-0298)

Weinbauer GF, Gromoll J, Simoni M \& Nieschlag E 2010 Physiology of testicular function. In Andrology: Male Reproductive Health and Dysfunction, pp 11-60. Eds E Nieschlag, HM Behre \& S Nieschlag. Berlin: Springer-Verlag.

Welter H, Kohn FM \& Mayerhofer A 2011 Mast cells in human testicular biopsies from patients with mixed atrophy: increased numbers, heterogeneity, and expression of cyclooxygenase 2 and prostaglandin D2 synthase. Fertility and Sterility 96 309-313. (doi:10.1016/j.fertnstert. 2011.05.035)

Welter H, Kampfer C, Lauf S, Feil R, Schwarzer JU, Kohn FM \& Mayerhofer A 2013 Partial loss of contractile marker proteins in human testicular peritubular cells in infertility patients. Andrology 1 318-324. (doi:10.1111/j.2047-2927.2012.00030.x)

Winnal WR, Ali U, O'Bryan MK, Hirst JJ, Whiley PA, Muir JA \& Hedger MP 2007 Constitutive expression of prostaglandin-endoperoxide synthase 2 by somatic and spermatogenic cells is responsible for prostaglandin E2 production in the adult rat testis. Biology of Reproduction 76 759-768. (doi:10.1095/biolreprod.106.053124)

Received 1 August 2014

First decision 8 October 2014

Revised manuscript received 27 November 2014

Accepted 11 December 2014 